\title{
Fair Housing and the Constitutionality of Governmental Measures Aff ecting Community Ethnicity
}

\author{
Dorn Bishop $\dagger$
}

In response to a continuing exodus of blacks from urban settings, ${ }^{1}$ a number of traditionally white suburbs have sought, using one device or another, to limit black entry into their communities. ${ }^{2}$ These measures affecting community ethnicity (MACEs) ${ }^{3}$ can assume a wide variety of forms, ranging in degree from direct ceiling quotas on black population, ${ }^{4}$ to implicitly race-conscious entice-

$\dagger$ B.A., 1985, Dartmouth College; J.D. Candidate, 1989, University of Chicago.

1 Statistics from the 1980 census for thirteen large American cities show blacks increasingly moving to the suburbs. Only in New York City did the flow of blacks to the suburbs decrease between 1960-1970 and 1970-1980. See Eugene Carlson, Blacks Increasingly Head to Suburbs, Wall Street J 29 (Oct 20, 1981). See also Gary A. Orfield, Albert Woolbright and Helene Kim, Neighborhood Change and Integration in Metropolitan Chicago (Report of the Leadership Council for Metropolitan Open Communities, July 1984); William P. O'Hare, Blacks on the Move: A Decade of Demographic Change (Joint Center for Political Studies, 1982); Harold M. Rose, Black Suburbanization: Access to Improved Quality of Life or Maintenance of the Status Quo? (Ballinger, 1976).

2 See generally Rodney A. Smolla, In Pursuit of Racial Utopias: Fair Housing, Quotas, and Goals in the 1980's, 58 S Cal L Rev 947 (1985); Rodney A. Smolla, Integration Maintenance: The Unconstitutionality of Benign Programs that Discourage Black Entry to Prevent White Flight, 1981 Duke L J 891, 898-901; Bruce S. Gelber, Race-Conscious Approaches to Ending Segregation in Housing: Some Pitfalls on the Road to Integration, 37 Rutgers L Rev 921, 935-39 (1985); John M. Goering, ed, Housing Desegregation and Federal Policy (Univ of N C, 1986); Bruce A. Ackerman, Integration for Subsidized Housing and the Question of Racial Occupancy Controls, 26 Stan L Rev 245, 249-251 (1974); Note, Benign Steering and Benign Quotas: The Validity of Race-Conscious Government Policies to Promote Residential Integration, 93 Harv L Rev 938, 939-940 (1980).

3 I have chosen the acronym "MACE" over any collective, pejorative label so as to emphasize the merits of a particular program. To date, the labels ascribed to these programs have been largely a function of the authors' own perspectives. Thus, an opponent of all raceconscious programs has used the term "integration maintenance," Smolla, 1981 Duke L J 891 (cited in note 2), while proponents of these programs have referred to them as "affirmative marketing," Gelber, 37 Rutgers L Rev at 929 (cited in note 2) and "benign steering," Note, 93 Harv L Rev at 957-58 (cited in note 2).

- See United States v Starrett City Associates, 660 F Supp 668 (E D NY 1987), affd 840 F2d 1096 (2d Cir 1988), cert denied 55 USLW 3328 (Nov 8, 1988); Burney $v$ Housing Authority of County of Beaver, 551 F Supp 746 (W D Pa 1982); Williamsburg Fair Housing Committee $v$ New York City Housing Authority, 493 F Supp 1225 (S D NY 1980), aff'd and remanded without opinion, 647 F2d 163 (2d Cir 1981). See also Otero $v$ New York City Housing Authority, 484 F2d 1122 (2d Cir 1973). 
ments such as promotion and improved public facilities designed to retain the community's current white population. ${ }^{5}$ Between the two ends of the spectrum lie a number of race-conscious measures intended either to discourage the entry of blacks into designated areas, or to encourage the entry of whites. ${ }^{6}$

The purpose of these programs is not, as one might think, to undermine the benevolent goal of an integrated society. Rather, it is to preserve integration by keeping an already-achieved racial balance intact. The magnitude of the MACE employed often depends on community fears that black entry will prompt an accelerated "white flight" from the area; usually, the more immediate the need to allay community expectations of resegregation, the more drastic the MACE that will be implemented. Thus, MACEs are often implemented not so much to keep blacks out, as to keep whites in. Regardless of the type of measure employed, however, a paradoxical question arises: should the State be permitted to discriminate against individual blacks in order to promote the perceived interests of blacks as a class, and society generally?

This comment will examine the legality of MACEs under the Equal Protection Clause of the Fourteenth Amendment ${ }^{7}$ and the Fair Housing Act. ${ }^{8}$ While other provisions of the Constitution ${ }^{9}$ and

${ }^{5}$ See Comment, The Legality of Affirmative Measures to Achieve and Maintain Integration in a New Town, 59 Georgetown L J 335, 352 (1970); Victor S. Navasky, The Benevolent Housing Quota, 6 Howard L J 30, 38-40 (1960).

- See Alexander Polikoff, Sustainable Integration or Inevitable Resegregation, in John M. Goering, ed, Housing Desegregation 43, 44-45 (cited in note 2). For examples of litigation in this area, see South Suburban Housing Center v Greater South Suburban Board of Realtors, No 83-C-8149 (ND IIl) (filed Nov. 14, 1983); Linmark Associates, Inc. v Township of Willingboro, 431 US 85 (1977).

7 The Fourteenth Amendment to the United States Constitution reads, in pertinent part, "No State shall ... deny to any person within its jurisdiction the equal protection of the laws." The Fifth Amendment's Due Process Clause applies the same limitation to the federal government. Bolling $v$ Sharpe, 347 US 497 (1954).

${ }^{8}$ The Civil Rights Act of 1968, Title VIII, 42 USC $\S \S 3601-3619$ (1982).

- The Constitutional provisions under which MACEs might be questioned include the First Amendment, the Thirteenth Amendment, and the Due Process Clause of the Fourteenth Amendment. Under the First Amendment, see Linmark Associates, Inc. $v$ Township of Willingboro, 431 US 85 (1977) (anti-solicitation ordinance intended to stem white flight by banning "For Sale" and "Sold" signs held unconstitutional). Under the Thirteenth Amendment, see Jones v Alfred H. Mayer Company, 392 US 409, 439-43 (1968) ("when racial discrimination herds men into ghettos and makes their ability to buy property turn on the color of their skin, then it too is a relic of slavery"). See also Plessy v Ferguson, 163 US 537, 557 (1895) (Harlan dissenting) (suggesting that the right of locomotion cannot be taken away on grounds of race without an unconstitutional infringement on personal liberty). Under the Due Process Clause, see Buchanan v Warley, 245 US 60, 81-82 (1917) (city ordinance that forbade blacks from occupying houses on blocks where whites occupied the majority of houses denied whites their property right to sell their homes to blacks). 
federal statutes ${ }^{10}$ are also relevant, this comment will undertake a more restrictive study. Section I examines the theoretical basis, functions, and dangers of MACEs, and includes a discussion of "tipping," the sociological phenomenon that prompts "white flight" and necessitates the implementation of MACEs. Section II contains a survey of selected cases that have examined the legality of MACEs. Section III, in turn, analyzes the legality of MACEs. It begins by arguing that the standards of review under the Fair Housing Act are coterminous with those of the Equal Protection Clause. The section then evaluates the constitutionality of MACEs under a strict scrutiny analysis. The section concludes that, while all MACEs fulfill a "compelling" governmental end in principle, an ad hoc approach is necessary to determine when a MACE program is needed, and if the MACE is "narrowly tailored" toward the achievement of its objectives. Section IV outlines standards that courts should use when addressing these issues.

This comment concludes that all types of MACEs, including ceiling quotas, are constitutionally permissible as long as they meet certain criteria. At their most basic level, MACEs are designed to end the phenomenon of tipping by altering societal attitudes and, thereby, promote the goal of an integrated society. In the short run, MACEs act as a "band-aid," a State-created assurance that a community's tipping point will not be reached. In the long run, however, MACEs are more palliative; through State-created racial interaction, the racist perceptions that lie at the heart of white flight will dissipate. Theoretically, this will raise the community tipping point until it eliminates the tipping threat entirely.

This comment does not contend that more severe MACEs, such as ceiling quotas, will always be justified; any given MACE must always be narrowly tailored toward achieving the immediate end of preserving a particular community's racial balance. Any MACE, to be valid, must produce benefits from an integrated society that outweigh the costs imposed on individual blacks.

\section{The Theoretical Basis, Functions, and Dangers of MACEs}

\section{A. The Theoretical Basis of MACEs}

"Tipping" is a sociological term used to describe the tendency of whites, both individually and collectively, to leave a community

20 Most notably, the Civil Rights Act of 1866, 42 USC $\S 1982$ (1982), which guarantees the right of all citizens of the United States to "inherit, purchase, lease, sell, hold, and convey real and personal property." 
once the black population exceeds a certain critical mass, or "tipping point."11 Thomas C. Schelling has advanced a widely accepted theory of tipping grounded in the notion of converging individual expectations. ${ }^{12}$ Schelling explains that because individual behavior converges to create group dynamics, even a relatively slight increase in black population can trigger a chain reaction among virtually all whites to flee a community. This self-accelerating phenomenon can occur even where the vast majority of whites are willing to adapt to substantial black entry. Consider the following illustration of Schelling's theory. ${ }^{13}$ In a 100 unit housing complex with one white per unit, suppose that five whites cannot tolerate even one black living in the complex. Assume further that twentyfive more whites will flee the complex if the black population reaches five. Finally, assume that once the black population reaches thirty, substantially more whites will leave, and that even those who had chosen to remain will leave after these departures. If all of the departing whites are replaced by blacks, then the entry of one black will lead to resegregation. ${ }^{14}$ Note that throughout this scenario, "[t]he consequences are aggregate, but the decisions are exceedingly individual."'15 Tipping will result even though 70 percent of the community's residents would tolerate substantial black entry into the area.

While Schelling's theory is helpfully descriptive, it fails to explain the motivations for white flight from transitional areas. On the one hand, white flight might be prompted by expectations of the transition's possible economic effects, including declining property values, deteriorating schools and rising crime rates. On the other hand, tipping might be due to overt racial prejudice. In many cases, both of these reasons probably play a complementary role in causing white flight and resegregation. Schelling, however, does not address the extent to which lack of information supplied to whites causes either of these motivations, even though such an examina-

${ }^{11}$ See Thomas C. Schelling, A Process of Residential Segregation: Neighborhood Tipping, in Anthony H. Pascal, ed, Racial Discrimination in Economic Life 157-184 (Lexington Books, 1972); Smolla, 1981 Duke L J at 893-898 (cited in note 2); Navasky, 6 Howard L J at 34-37 (cited in note 5).

12 Schelling, Neighborhood Tipping at 163-168, 177-178 (cited in note 11). See also Thomas C. Schelling, On the Ecology of Micromotives, 25 Public Interest 61, 79-90 (Fall 1971); Thomas C. Scheiling, Micromotives and Macrobehavior 101 (Norton, 1978).

13 See Smolla, 1981 Duke L J at 894 (cited in note 2).

14 This conclusion assumes that the 70 vacated units will be occupied by blacks. Of course, theoretically, the white residents who leave could be replaced by whites with higher individual tipping points, so resegregation is not inevitable.

15 Schelling, 25 Public Interest at 81 (cited in note 12). 
tion is helpful in formulating the most efficient means to prevent tipping. ${ }^{16}$

This last point underscores perhaps the most fundamental issue left unaddressed by Schelling: how to predict a community's tipping point. Because his theory purports to be no more than a mathematical description of the tipping process, Schelling neither outlines relevant criteria in this regard, nor does he offer empirical evidence in support of the tipping phenomenon. One sociologist has commented that the tipping phenomenon remains both "scattered and impressionistic," and does not definitively determine whether neighborhoods in fact tip. ${ }^{17}$ Determining an area's tipping point, assuming that one even exists, can be difficult and imprecise. Thus, the practicalities of any particular situation could render determination of a community's tipping point a prohibitively costly undertaking.

\section{B. The Functions of MACEs}

\section{MACEs as a remedy for tipping.}

This comment will assume that the fundarnental end of all MACEs is the achievement of an integrated society and the societal benefits generated from long-term stable living patterns. ${ }^{18}$ Yet, such an end cannot be achieved naturally if one accepts the convergent-expectations model of tipping. In fact, Schelling argues that, given contemporary attitudes, the odds in favor of an integrated society naturally arising are virtually insurmountable..$^{19}$

Assuming Schelling's theory is valid, the only viable way to achieve an integrated society is to prevent tipping. This can be accomplished in two ways: either by keeping the black population below a community's current tipping point, or by increasing and ultimately eliminating that community's tipping point. As MACEs illustrate, however, these two methods need not be mutually exclusive, and both are demonstrated by the linear and non-linear effects of MACEs. "Linear" effects of MACEs refer to those that are

18 See John Yinger, On the Possibility of Achieving Racial Integration through Subsidized Housing, in Goering, ed, Housing Desegregation 290, 296 (cited in note 2).

${ }_{17}$ John M. Goering, Neighborhood Tipping and Racial Transition: A Review of Social Science Evidence, $44 \mathrm{~J}$ Am Inst Planners 68, 69 (1978). For background on the tipping debate, see Yinger, in Housing Desegregation at 294-98; Navasky, 6 Howard L J at 34-37 (cited in note 5).

${ }^{18}$ One should not confuse the "function" of MACEs (to prevent tipping) with the "ends" of all MACEs (to achieve an integrated society).

19 Schelling, 25 Public Interest at 82-88 (cited in note 12). 
produced only gradually and over time. These effects stand in contrast to "non-linear" effects, i.e., those that are produced immediately upon a MACE's implementation.

The first method of preventing tipping, keeping the black population below a community's current tipping point, is demonstrated by a non-linear effect of MACEs. MACEs are designed to maintain a racial balance such that, at any given time, the community's black population will not exceed the critical mass needed to trigger tipping. Once a particular community has approximated its tipping point, it will employ MACEs to maintain a black population level reasonably beneath that estimated tipping point. In both calculating the tipping point and in setting the target level, courts must be mindful of the potential for intentional overexclusion of blacks from the community under the guise of preventive measures. ${ }^{20}$

The second method of preventing tipping, increasing a community's tipping point, is illustrated by both a non-linear and a linear effect of MACEs. First, MACEs will increase a community's tipping point by immediately and continuously allaying expectations that the community is on the verge of complete resegregation, provided of course that the community is aware of the State's efforts and believes in their efficacy. This is a non-linear function because, at any given time after the implementation of the MACE, the community's tipping point will be uniformly higher than in its absence.

In addition to this non-linear effect, time allows MACEs to increase a community's tipping point. Gradually, racially balanced living patterns will alter community attitudes toward blacks. Greater interaction will lead to greater understanding and reduced tension between the races. The end result will be an ever-increasing community tipping point, and consequently far less potential for resegregation; ultimately, MACEs will be unnecessary. ${ }^{21}$ Thus,

${ }^{20}$ See generally Califano $v$ Webster, 430 US 313, 317 (1977) (" '[T] a benign, compensatory purpose is not an automatic shield which protects against any inquiry into the actual purpose underlying a statutory scheme" ") (quoting Weinberger $v$ Wiesenfeld, 420 US 636, 648 (1975)).

${ }^{21}$ This argument bears some similarity to the theory of the "universalist ethic", the basic premise of which is that

a stable, just society, without violence, alienation, and social discord, must be an integrated society. Segregation of the races in public institutions, employment and housing will inevitably lead to conflict and the destruction of democratic values and institutions. In short, the goal is a shared culture in which all segments of the population participate.

Mark G. Yudof, Equal Educational Opportunity and the Courts, 51 Tex L Rev 411, 457 
while MACEs serve as a band-aid for the disease of tipping in the short-term, such measures operate as a cure for that disease in the long run. ${ }^{22}$

\section{MACEs as remedies for identified discrimination.}

MACEs can serve an entirely different purpose in some circumstances. In those instances where prior civil rights violations have created unnatural residential patterns, ${ }^{23}$ MACEs can function as a race-conscious remedy for that violation. ${ }^{24}$ The most oft-cited culprit in this regard has been the real estate industry, which has participated in a number of racially discriminatory housing policies, including racial steering and "blockbusting." ment of Housing and Urban Development has noted that "discrimination in the housing market continues to be a common and widespread problem." ${ }^{26}$ Such a statement appears somewhat justified. Until 1950, for example, the Code of Ethics for the National Association of Real Estate Boards prohibited realtors from selling homes in white neighborhoods to blacks since, it was claimed, integration would decrease property values. ${ }^{27}$ While the real estate industry might not actively discriminate as much as it once did, it

(1973).

${ }^{22}$ Polikoff, Sustainable Integration or Inevitable Resegregation at 45 (cited in note 6).

${ }^{23}$ See, for example, Clark v Universal Builders, Inc., 501 F2d 324, 334 (7th Cir 1974) ("the existence of dual housing markets" for whites and blacks in the Chicago metropolitan area and the economic exploitation of that situation by defendant homebuilders violated $\S$ 1982).

${ }^{24}$ For cases speaking favorably of remedial MACEs designed to attract blacks to a community rather than deter them, see United States $v$ Yonkers Bd. of Educ., 635 F Supp 1577, 1579 (S D NY 1986), aff'd 801 F2d 593 (2d Cir 1987); Jenkins v State of Missouri, 593 F Supp 1485, 1499-1500 (W D Mo 1984), aff'd as Jenkins by Agyei $v$ State of Missouri, 807 F2d 657 (8th Cir 1986); Alschuler v HUD, 515 F Supp 1212, 1233-34 (N D Ill 1981), aff'd and remanded, 686 F2d 472 (7th Cir 1982); United States v Pelzer Realty Co., Inc., 537 F2d 841 (5th Cir 1976).

${ }^{26}$ See generally Note, Racial Steering: The Real Estate Broker and Title VIII, 85 Yale L J 808, 812 (1976); Gelber, 37 Rutgers L Rev at 922 (cited in note 2); Note, 93 Harv L Rev at 943-44 (cited in note 2). For cases involving realtor steering, see, for example, Gladstone, Realtors $v$ Village of Bellwood, 441 US 91 (1979); Zuch v Hussey, 394 F Supp 1028 (E D Mich 1975) (broker advice that discourages white buyers from purchasing in black areas violates the Fair Housing Act). But see South Suburban Housing Center, No 83-C-8149 (N D Ill) (filed Nov. 14, 1983) (allegation of ongoing municipality discrimination against blacks); United States v City of Parma, 494 F Supp 1049 (N D Ohio 1980) (municipality held liable for failing to take steps aimed at rectifying racially discriminatory housing patterns).

${ }^{20}$ Harriet Newburger, Recent Evidence on Discrimination in Housing (US Dept of Housing and Urban Development, 1984).

${ }^{27}$ Gelber, 37 Rutgers L Rev at 922 n 9 (cited in note 2) (citing Rose Helper, Racial Policies and Practices of Real Estate Brokers 201 (Univ of Minn, 1969)). 
continues to employ marketing media and methods that often perpetuate dual housing by catering to selected racial groups. ${ }^{28}$

While the MACE is an arguably valid device for remedying identified discrimination, this comment will focus instead on nonremedial MACEs, i.e., MACEs used exclusively as a remedy to the tipping phenomenon. There are two reasons for this approach. First, since this comment argues that non-remedial MACEs are not per se unconstitutional, it follows a fortiori that remedial MACEs are not per se unconstitutional. ${ }^{29}$ Second, racial discrimination by specified actors, whether realtors, municipalities, or developers, might admittedly lead to skewed living patterns. However, an underlying principle of the tipping phenomenon is that, even left unaffected by such practices, present expectations and perceptions effectively preclude long-term integrated living patterns from arising. Thus, remedial MACEs, unless structured so as to entail nonremedial MACE effects, may prevent discrimination but will do nothing to prevent white flight from perpetuating segregated living patterns. As Gary Orfield has written, "The lessons show that the achievement of the gains of stable integration on a large scale requires an explicit goal of integration, rather than nondiscrimination alone."

\section{Different Types of MACEs.}

In one sense, all MACEs are exactly alike: they are all race conscious measures designed to maintain a community's racial equilibrium in the short term and to promote naturally occurring integrated living patterns in the long term. Indeed, the only facially distinguishable characteristic among the various forms of MACE may be their effectiveness, that is, the degree to which each MACE affects a community's ethnic make-up and its residents' expectations about tipping. Because of this underlying similarity, this comment will argue that the courts should, in principle, treat

${ }^{28}$ See George C. Galster, More than Skin Deep: The Effect of Housing Discrimination on the Extent and Pattern of Racial Residential Segregation in the United States, in John M. Goering, ed, Housing Desegregation 119, 133-34 (cited in note 2). Many courts have taken judicial notice of this "dual housing market" in the context of individual metropolitan housing markets. See, for example, Jenkins, 593 F Supp at 1491; Clark, 501 F2d at 334-35.

${ }^{29}$ It bears emphasis that "non-remedial" MACEs are only non-remedial in the sense that they are not intended to remedy prior civil rights violations by a specific actor; they are, however, quite ameliorative of the effects brought about by prior and ongoing societal discrimination.

${ }^{30}$ Gary Orfield, The Movement for Housing Integration: Rationale and the Nature of the Challenge, in Goering, ed, Housing Desegregation 18, 25 (cited in note 2). 
all MACEs exactly alike.

Although MACEs may take various forms, two general categories may be identified: MACE quotas and less direct MACEs. MACE quotas serve both as ceiling quotas limiting the black population to a specified percentage, and as access quotas, guaranteeing a minimum black population of that size. ${ }^{31}$ The Justice Department recently attacked such quotas as constituting impermissible racial discrimination. ${ }^{32}$ Minority individuals who have been denied access to housing and housing groups representing them have also attacked such quotas. ${ }^{33}$ One prominent black author has compared the motivation and effect of MACE quotas to that of restrictive racial covenants, ${ }^{34}$ and the NAACP Legal Defense Fund has, for the first time, challenged the legality of a MACE quota. ${ }^{35}$ Nevertheless, the national NAACP and most other organizations representing blacks have, to date, consciously refrained from expressing any official opinion on the desirability of MACE quotas.

Less direct MACEs, sometimes referred to collectively as "affirmative marketing," take the form of policies that seek, through education or incentives, to persuade homeseekers of a particular racial or ethnic group to make housing choices that will further the goal of residential integration. ${ }^{36}$ These MACEs may take a wide variety of forms, including governmental subsidies to private housing referral agencies in order to "counsel" homeseekers, ${ }^{37}$ promo-

31 See Gelber, 37 Rutgers L Rev at 929 (cited in note 2) (calling such quotas "benign"); Linda M. Vodar, The Use of Racial Housing Quotas To Achieve Integrated Communities: The Oak Park Approach, 6 Loyola U Chi L J 164 (1975).

${ }^{32}$ See United States v Starrett City Associates, 660 F Supp 668 (E D NY 1986), aff'd 840 F2d 1096 (2d Cir 1988). The Justice Department also recently filed suit against a housing complex in metropolitan Chicago, Atrium Village, for using racial quotas that limit black entry. See Dirk Johnson, U.S. Sues Integrated Housing Complex in Chicago on Use of Racial Quotas, New York Times A1, D19 (July 24, 1987). A black tenant who had been denied housing had already filed a suit challenging the housing complex's practices. See United States v Atrium Village Association, No 87-C-6527 (N D Ill) (filed July 23, 1987).

${ }^{33}$ See Burney v Housing Authority, 551 F Supp 746 (W D Pa 1982), aff'd 735 F2d 113 (3d Cir 1984); Williamsburg Fair Housing Committee v New York City Housing Authority, 493 F Supp 1225 (S D NY 1980), aff'd and remanded without opinion, 647 F2d 163 (2d Cir 1981).

${ }^{34}$ Derrick A. Bell, And We Are Not Saved 153 (Basic Books, 1987). D III).

35 The organization has intervened as a co-plaintiff in Atrium Village, No 87-C-6527 (N

${ }^{36}$ See Gelber, 37 Rutgers $L$ Rev at 929 (cited in note 2).

${ }^{37}$ See South Suburban Housing Center, No 83-C-8149 (N D III). The Cleveland suburb of Shaker Heights has such a program, which provides housing assistance only to blacks seeking entry into predominantly white communities and to whites seeking to move into black or transitional neighborhoods. See Smolla, $58 \mathrm{~S}$ Cal L Rev at 947, 954-55 (cited in note 2). 
tional campaigns aimed toward selected audiences, ${ }^{38}$ priority to one group for occupancy in new housing, ${ }^{39}$ site selection for new housing, ${ }^{40}$ increased monitoring of realtor steering activity through the use of "testers," 41 prosecuting infractions wherever possible, ${ }^{42}$ promoting high quality education, public facilities, and police security, ${ }^{43}$ and screening for potentially disruptive housing applicants. ${ }^{44}$ Although they share the same goal as quotas, these less direct MACEs contain no explicit racial classification and thus are difficult to challenge in court.

One should not conclude, however, that less direct MACEs will invariably produce a living pattern identical to that of a quota. There will be some instances where the maximum effect from manipulating choice will fall short of the stated goals for racial balance. ${ }^{45}$ In such cases, no MACEs short of a quota will be able to prevent tipping. Therefore, sometimes MACE quotas will be the only viable means of integrating the community.

\section{The Dangers of MACEs}

Any implementation of MACEs potentially will entail significant error costs, as well as costs to individual blacks who are negatively influenced by MACEs, however subtly, and costs to black political power and cultural innovation. Thus, even where MACEs do effectively prevent white flight, the costs of preventing white flight may be too great; a less direct form of MACE, or no MACE at all, may ultimately be preferable. ${ }^{46}$ The balanceable costs involved in either of these alternatives reflect that the debate over

${ }^{38}$ See South Suburban Housing Center, No 83-C-8149 (N D III). For an example of what such newspaper advertisements look like, see Classified Real Estate Section, The Star (April 11, 1985) (on file with Business \& Professional People for the Public Interest, Chicago, Illinois).

${ }^{39}$ See Otero $v$ New York City Housing Authority, 484 F2d 1122 (2d Cir 1973).

10 See Gautreaux v Chicago Housing Authority, 296 F Supp 907 (N D Ill 1969); United States $v$ City of Parma, Ohio, 494 F Supp 1049 (N D Ill 1980). See also Navasky, 6 Howard $\mathrm{L} J$ at $38-39$ (cited in note 5 ).

${ }^{41}$ See Haven Realty Corp. v Coleman, 455 US 363 (1982); Gladstone Realtors $v$ Village of Bellwood, 441 US 91, 94 (1979).

42 See Gladstone Realtors, 441 US 91 (1979).

${ }^{43}$ Comment, 59 Georgetown L J at 352 (cited in note 5).

"4 Id. Although "racially neutral" on their face, these activities may be implicitly raceconscious because communities might undertake them to influence particular racial groups.

${ }^{45}$ See Goering, Introduction, in Housing Desegregation at 197, 202 (cited in note 2) (citing National Capitol Systems, Assessment of HUD's Affirmative Fair Housing Marketing Program (Final Report), (Office of Policy Development and Research, Department of Housing and Urban Development, April 1983)).

${ }^{46}$ See Paul Gewirtz, Remedies and Resistance, 92 Yale L J 585, 642 (1983). 
MACEs presents "not a choice between absolutism and the imperfect, but a choice among the imperfect."47

\section{Error costs.}

As previously noted, the tipping hypothesis is not a universally accepted theory, and it remains uncertain how one may accurately calculate or predict any given community's tipping point. ${ }^{\mathbf{4}}$ This as yet unrefined predictive process introduces a number of potential error costs into the MACE calculus. An inaccurately low goal or quota for the black population places a burden on those blacks who are prevented or dissuaded from living in a community, but need not be.

This error cost would be relatively slight if a community's tipping point were easily ascertainable. An early study of tipping, however, estimated that any particular community's tipping point could range anywhere from 20 to 60 percent. ${ }^{49}$ Most studies have since estimated that the majority of communities' tipping points are between 25 and 30 percent. $^{.0}$ Even with a MACE target level within this range, though, tipping may still result, or the level may be set too high and may unnecessarily discriminate against some individual blacks. Communities conceivably could examine their own tipping points in an ad hoc fashion, addressing such factors as white residents' and prospective entrants' expectations about changes in the character of the community, fears of a decline in property values, and tolerance for black neighbors. ${ }^{51}$ Yet this approach might entail prohibitive administrative and fact-gathering costs, all with no guarantee of successfully calculating the correct tipping point.

\section{Costs to individual blacks.}

Every black prospective homebuyer above the community's targeted MACE point is burdened to some degree by the effects of the MACE. MACE quotas produce the most direct cost, where blacks who want to live in an area are not permitted to do so. Even if a black is not prohibited from buying a home, however, any discrimination against that black or in favor of a white necessarily

47 Id at 660 .

18 See notes $11-17$ and accompanying text.

19 Navasky, 6 Howard $\mathrm{L} J$ at 34-35 (cited in note 5).

${ }^{30}$ See, for example, Goering, $44 \mathrm{~J}$ Am Inst Planners 68 (cited in note 17); Note, $93 \mathrm{Harv}$ $\mathrm{L}$ Rev at 942 (cited in note 2).

s1 See Note, 93 Harv L Rev at 942 (cited in note 2). 
imposes the cost of looking elsewhere for a house. It also infringes on individual liberty, in that blacks' choices are being manipulated.

Alexander Polikoff has argued that, while ceiling quotas restrict housing choices, other MACEs, such as affirmative marketing and promotional devices, in no way limit or manipulate choice. ${ }^{52}$ This is true in a remedial context, where MACEs expand choice by eliminating previous discriminatory constraints on blacks. However, in the non-remedial context, where there is no ex ante restriction on free choice, any steering would reprioritize rather than expand existing choices, and thus restrict liberty.

\section{Political and remedial costs.}

An unfortunate consequence of MACEs is that blacks, in the process of becoming increasingly diffused throughout society, will lose some measure of political power. One could argue that the greater the dispersal of blacks in society, the greater their influence will be. However, experience has demonstrated that a minority group enjoys its greatest political power when that group is concentrated and thereby more easily united and organized. ${ }^{53}$ One commentator, in fact, has argued that the white majority implements MACE quotas merely to ensure that blacks are outnumbered and powerless. ${ }^{54}$

This last point is closely connected to another argument, viz., that MACE quotas are designed to retain white economic power. The argument runs as follows: while resegregation reduces property values from the perspective of white homeowners, it in fact permits blacks entering the community to enjoy higher property values relative to their situation prior to entry. In effect, then, MACEs act as invidious devices that hold black economic power in check, and act precisely contrary to their purportedly remedial purpose; they prevent the equitable redistribution of property to blacks, and provide instead a baseline windfall to the white major-

${ }^{52}$ Alexander Polikoff, What's In A Name?-The Diversity of Racial Diversity Programs, in 1 Issues in Housing Discrimination: A Consultation/Hearing of the United States Commission on Civil Rights 200, 202 (1986).

${ }^{53}$ See John Kaplan, Equal Justice in an Unequal World: Equality for the Negro-The Problem of Special Treatment, $61 \mathrm{Nw}$ U L Rev 363, 397-98 (1966).

${ }^{54}$ See Alan David Freeman, Racial Discrimination Through Antidiscrimination Law: A Critical Review of Supreme Court Doctrine, 62 Minn L Rev 1049, 1076 (1978). See also, Bell, And We Are Not Saved at 153 (cited in note 34), arguing that MACE quotas "reflect a desire by whites to dominate their residential and nonresidential environments." 
ity by means of preserving the status quo. ${ }^{55}$ Of course, this argument assumes the unavailability to blacks of other communities with comparable property values, which is unlikely to occur in practice.

\section{Cultural costs.}

The black cultural identity that has emerged from three centuries of black social subordination in this country may diminish as MACEs fulfill their function and blacks become increasingly diffused and assimilated throughout traditionally white communities. Some might argue that these cultural costs should be factored into the cost-benefit calculus of MACEs. ${ }^{56}$ However, that the cultural costs produced by MACEs may be unavoidable does not alone require these costs to be balanced. It would be quite ironic to maintain that, because cultural contributions have emerged from the evils wrought by white subordination of blacks, these contributions provide sufficient moral impetus to justify the perpetuation of the same morally corrupt, segregated society that prompted such contributions in the first place. ${ }^{57}$ Thus, loss of cultural innovation may be a regrettable by-product of the moral imperative of integration, and therefore a cost to society at large, but it should not be a factor in determining the validity of MACEs.

\section{Selected Cases Involving MACEs}

To date, there have been relatively few cases that have addressed the legality of MACEs, and most of these have involved fairly explicit MACEs. Because of this, it is somewhat difficult to define the current state of the law in this area, especially for direct MACEs. Nevertheless, one can discern a loose set of rules and principles from the cases.

Generally speaking, a MACE plan will not be upheld unless it is supported by demonstrable and sizable evidence of a tipping threat, replete with a well-documented estimation of the precise

${ }^{65}$ See Bell, And We Are Not Saved at 153 (cited in note 34). See also Cass R. Sunstein, Lochner's Legacy, 87 Colum L Rev 873, 894-98 (1987); Herbert Wechsler, Toward Neutral Principles of Constitutional Law, 73 Harv L Rev 1 (1959).

ss See Kaplan, $61 \mathrm{Nw}$ U L Rev at 398 (cited in note 53). See also Nathan Glazer and Daniel Patrick Moynihan, Beyond the Melting Pot 24-85 (MIT Press, 1963), and, generally, Nathan Glazer and Daniel Patrick Moynihan, eds, Ethnicity: Theory, and Experience (Harvard Univ Press, 1975).

57 See Richard Lempert, The Force of Irony: On the Morality of Affirmative Action and United Steelworkers v. Weber, 95 Ethics 86 (1987). 
point at which tipping will occur. In addition, a court will require a showing that the MACE chosen is the least intrusive means toward the specific end of preventing tipping. If a court strikes down a MACE, it will almost certainly do so on statutory rather than constitutional grounds. Finally, even if a MACE is upheld, a court will require that the MACE cease once a particular racial balance is achieved, regardless of how unstable that racial balance may be.

\section{A. The Second Circuit's Treatment of MACEs}

Otero $v$ New York City Housing Authority ${ }^{58}$ was the first direct ruling in favor of race-conscious measures designed to maintain residential integration. Racial minorities, who had been relocated to permit construction of a public housing project, challenged the housing authority's decision to give whites priority to live in the new project in disregard of its own priority regulations. ${ }^{5 \theta}$ The Second Circuit reversed the district court's grant of summary judgment for the plaintiffs on equal protection and statutory grounds. Nevertheless, the court held that, on remand, the defendants would carry a "heavy burden" of proving that resegregation would "probably" occur in the absence of a MACE ceiling. ${ }^{80}$ From this it can be inferred that, in the court's view, the benefits from preventing tipping could outweigh the cost of limited access and stigma to blacks. However, it bears emphasis that Otero, in 1973, preceded many landmark Supreme Court decisions addressing affirmative action, including University of California Regents $v$ Bakke. ${ }^{61}$

The continuing vitality of the Otero decision has become questionable in light of two subsequent Second Circuit decisions, Williamsburg Fair Housing Committee v N.Y. City Housing Authority $^{62}$ and United States $v$ Starrett City Associates. ${ }^{63}$ In Williamsburg, housing groups and minority individuals brought suit under the Fair Housing Act and the Equal Protection Clause to enjoin the use of MACEs in Williamsburg's publicly assisted housing. A consent decree followed in which most of the parties agreed to permit the use of race in order to attain certain desired

s8 484 F2d 1122 (2d Cir 1973).

${ }^{69}$ Id at 1124.

${ }^{B 0}$ Id at 1136.

${ }^{61} 438$ US 265 (1978).

62 493 F Supp 1225 (S D NY 1980), aff'd and remanded without opinion, 647 F2d 163 (2d Cir 1981).

${ }^{\text {63 }} 660$ F Supp 668 (E D NY 1987), aff'd 840 F2d 1096 (2d Cir 1988), cert denied 55 USLW 3328 (Nov 8, 1988). 
levels of integration. However, once such levels were reached in a particular complex, the consent decree provided that classifications based on race, color, religion, sex, or national origin would cease. ${ }^{64}$

One Williamsburg housing development that had implemented an extremely rigorous MACE quota program opposed enforcement of the consent decree against itself and all other parties. The district court found that this defendant, the Bedford Gardens housing complex, had implemented a quota of 75 percent white tenants, 20 percent Hispanic tenants, and 5 percent black tenants. ${ }^{65}$ Finding a violation of the Fair Housing Act's antidiscrimination policies, the court directed Bedford Gardens to obey the terms of the consent decree. In distinguishing Otero, the district court emphasized that the defendant might have justified such quotas by a showing of a tipping threat, but absent such a showing it could not meet the "heavy burden mandated by Otero."66

United States $v$ Starrett City Associates ${ }^{67}$ likewise involved the legality of a MACE quota. For years, Starrett City, the largest federally assisted housing development in the United States, had discriminated against minorities in order to maintain a racial balance of approximately 64 percent white, 23 percent black, 8 percent Hispanic, and 5 percent Asian. ${ }^{68}$ Several black applicants sued Starrett City and the State of New York under the Equal Protection Clause and the Fair Housing Act. ${ }^{68}$ A settlement in 1984 allowed Starrett City to continue implementation of its MACE quota, but provided for an 8 percent increase in minority occupancy. ${ }^{70}$

Soon thereafter, the federal government brought action against the housing complex under the Fair Housing Act. Despite the defendant's contention that such quotas were necessary to prevent tipping, a New York district court relied on a colorblind reading of Title VIII to strike down the MACE quotas. ${ }^{71}$ In support of its holding, the court cited evidence indicating the imprecise nature of predicting any given area's tipping point. ${ }^{72}$ Additionally,

34 493 F Supp at 1228-29.

${ }^{65}$ Id at 1231 .

s6 Id at 1249-50.

62660 F Supp 668 (E D NY 1987).

${ }^{68}$ Alan Finder, Complex to Halt Its Use of Quotas, New York Times 9 (National Edition) (Nov 8, 1988).

${ }^{69}$ Arthur v Starrett City Associates, 89 Fed Rules Dec 542 (E D NY 1981).

70 William G. Blair, Accord in Minority Suit Provides for More Subsidized Apartments, New York Times B4 (May 3, 1984).

72660 F Supp at 677-79.

${ }^{72}$ Id at 674-78. The defendant's own expert testified that an area's tipping point could 
the court explicitly rejected the need for MACEs to achieve integrated living patterns, stating that "large-scale racial integration in housing requires ... total open occupancy allowing minorities complete access to all housing ....' "'73

A divided Second Circuit Court of Appeals panel affirmed the district court's holding as it applied to Starrett City, but left open the possibility that other, less explicit MACEs might still be permissible under the Fair Housing Act. ${ }^{74}$ Rather than give Title VIII a colorblind, literal reading that might have banned all MACEs, the court invalidated the Starrett City plan because it was not temporary in nature, was not based on a finding of past discrimination against blacks, and thus was overburdensome to the blacks it affected. The court did not overrule Otero, but distinguished that case as involving a temporary, single event that determined tenancy in the first instance, and as a less burdensome device to blacks than the ongoing Starrett City plan. ${ }^{75}$

In dissent, Judge Newman argued that the legislators who enacted Title VIII never considered whether they wished to prevent maintenance of racially balanced housing, and thus never intended for the statute to forbid such voluntary action. Additionally, in criticizing the majority's treatment of Otero as involving a measure limited in duration, Newman wrote:

I see nothing in the text or legislative history of Title VIII that supports such a distinction. If, as the Court holds, Title VIII bars Starrett City's race-conscious rental policy, even though adopted to promote and maintain integration, then it would bar such policies adopted on a short-term or a longterm basis. ${ }^{76}$

The dissent has a point. In distinguishing Otero, the majority seems to have relied on the court-imposed requirement that an affirmative action program be temporary in nature. ${ }^{77}$ Since the phenomenon of tipping does not exist in the employment context, however, the parallel between Title VII and VIII appears to be

range "from a low of $1 \%$ black to a high of $60 \%$ black." Id at 678 .

${ }^{73}$ Id at 676 (quoting Morris Milgram, Good Neighborhood: The Challenge of Open Housing 208 (Norton, 1977)).

${ }^{74}$ United States v Starrett City Associates, 840 F2d 1096, 1102 (2d Cir 1988), cert denied 55 USLW 3328 (Nov 8, 1988).

78 Id at 1103.

${ }_{76}$ Id at 1107.

77 See Wygant $v$ Jackson Board of Education, 476 US 267, 275 (1986); Johnson v Transp. Agency, Santa Clara Cty., Cal., 107 S Ct 1442, 1451 (1987) citing United Steelworkers $v$ Weber, 443 US 193, 208 (1979). 
inapplicable. ${ }^{78}$

\section{B. Other Recent Cases}

Burney $v$ Housing Authority of County of Beaver ${ }^{78}$ also involved a MACE quota, implemented by the Housing Authority of Beaver County, Pennsylvania, in order to combat a perceived threat of tipping. Whenever the racial balance of a particular project deviated from the black/white ratio of the entire housing authority, priority would be given to the underrepresented racial group for housing in that project. The case involved a challenge to the program by a group of black women who, as a result of the plan, had been placed on a waiting list for placement in one of the housing authority's projects. ${ }^{80}$

Although the district court struck down the particular plan on constitutional and statutory grounds, it did not reject the use of alternative, less direct MACEs. Most significantly, the court implied that, under a cost-benefit approach, MACE quotas might nonetheless be justified in some circumstances:

"Benign" housing quotas are impermissible if they restrict black entry into low-income housing more than is necessary to prevent tipping and resegregation. When the percentage of black residents is kept below the tipping point, the quota imposes unnecessary costs on black entrants, serving the invidious purpose of exclusion more than the benign purpose of integration. There is no evidence at all before this court to indicate that the defendants' plan includes as many black residents as is compatible with the need to avoid resegregation. ${ }^{81}$

The court specifically rejected the defendants' contention that existing integration would necessarily be destroyed absent an explicit MACE quota. ${ }^{82}$ Instead, it cited alternative, less intrusive measures that might be used, such as a countywide waiting list for housing applicants. This, the court said, would facilitate the dispersal of applicants who would otherwise be confined to a single project's waiting list for an indefinite length of time. ${ }^{83}$

A final case involving the legality of MACEs, albeit a less di-

\footnotetext{
78 See the discussion on the temporary nature of a MACE program in Section III.D.5.

7551 F Supp 746 (W D Pa 1982).

so Id at 748,750 .

81 Id at 767 .

s2 Id at 765-66.

s3 Id at 765 .
} 
rect MACE program than those previously discussed, is currently pending in U.S. District Court for the Northern District of Illinois. ${ }^{84}$ As owner of three rehabilitated homes, the South Suburban Housing Center had entered into a listing agreement with a local broker that called for advertising efforts to be directed at whites. When the local multiple listing service refused the listings on the ground that such advertising constituted a violation of the Fair Housing Act, the Housing Center brought suit. Since the inception of the case, the National Association of Realtors has been joined as a defendant, and nine suburbs of Chicago, who worked with the Housing Center in promoting MACE policies throughout the area, have in turn been joined as counterdefendants. ${ }^{85}$

\section{The Constitutionality of MACEs}

\section{A. The Fair Housing Act and the Equal Protection Clause}

Of those federal statutes and constitutional provisions under which MACEs might be considered illegal, ${ }^{86}$ the two most often mentioned are the Fair Housing Act of 1968 (Title VIII) ${ }^{87}$ and the Equal Protection Clause of the Fourteenth Amendment.8 ${ }^{88}$ Government measures intended to limit the entry of blacks in order to promote integrated communities constitute steering on the basis of race. While steering designed to preserve segregated living patterns is forbidden under the Fair Housing Act, "benign steering" intended to foster and maintain integrated living patterns raises entirely different concerns. Legislative history, in this regard, has been deemed "not too helpful." No Nevertheless, federal courts, looking beyond Title VIII's colorblind language, have read its

84 South Suburban Housing Center, No. 83-C-8149 (N D Ill) (filed November 14, 1983).

${ }_{85}$ The suburbs include Blue Island, Calumet Park, Country Club Hills, Glenwood, Hazel Crest, Matteson, Park Forest, Richton Park, and University Park. Press Release of the National Ass'n for the Advancement of Colored People, Chicago Far-South Suburban Branch (June 1984) (on file with Business and Professional People for the Public Interest, Chicago, Illinois).

${ }^{86}$ See notes 9 and 10.

87 The Civil Rights Act of 1968, Title VIII, 42 USC $\$ \$ 3601-3619$ (1982).

${ }^{88}$ For articles mentioning these two provisions, see, for example, Note, 93 Harv L Rev 938 (cited in note 2); Smolla, 58 So Cal L Rev 947 (cited in note 2); Comment, The Benign Housing Quota: A Legitimate Weapon to Fight White Flight and Resulting Segregated Communities?, 42 Fordham L Rev 891 (1974).

88 Trafficante $v$ Metropolitan Life Ins. Co., 409 US 205, 210 (1972). Title VIII was offered as a floor amendment and there were no committee reports. See 114 Cong Rec 2270, 2270-84, 3421-24 (1968). For a general background of Title VIII's truncated legislative history, see Jean Eberhart Dubofsky, Fair Housing: A Legislative History and a Perspective, 8 Washburn L J 149 (1969). 
broad purpose, "to provide, within constitutional limitations, fair housing throughout the United States," sional intent to create "truly integrated and balanced living patterns." "In addition, the courts have repeatedly stressed " "the importance' to a community of 'promoting stable, racially integrated housing." "92

Thus, although the Fair Housing Act literally prohibits any discrimination based on race, and is thus "colorblind," the policies of the Act necessarily mandate race-conscious measures in some circumstances. The Supreme Court has upheld race-conscious measures under other "colorblind" statutes, most notably Title $\mathrm{VI}^{93}$ and Title VII ${ }^{94}$ of the Civil Rights Act of 1964 and under the Fourteenth Amendment. ${ }^{95}$ It is unclear, however, whether Title VIII is coterminous with the Fourteenth Amendment, like Title

๑0 42 U.S.C. $\S 3601$. The statute does not define "fair housing." The pertinent colorblind language is contained in 42 USC $\S 3604$, which states:

[I]t shall be unlawful-

(a) To refuse to sell or rent ... or otherwise make unavailable or deny, a dwelling to any person because of race, color, religion, sex, or national origin.

(b) To discriminate against any person in the terms, conditions, or privileges of sale or rental of a dwelling, or in the provision of services or facilities in connection therewith, because of race, color, religion, sex, or national origin.

(c) To make, print, or publish, or cause to be made, printed, or published any notice, statement, or advertisement, with respect to the sale or rental of a dwelling that indicates any preference, limitation, or discrimination based on race, color, religion, sex, or national origin ...

(d) To represent to any person because of race, color, religion, sex, or national origin that any dwelling is not available for inspection, sale, or rental when such dwelling is in fact so available.

21 Trafficante, 409 US at 211 (quoting with approval remarks of Senator Walter Mondale, 114 Cong Rec 3422 (1968)). However, Senator Mondale, the amendment's sponsor, also said, "The basic purpose of this legislation is to permit people who have the ability to do so to buy any house offered to the public if they can afford to buy it." 114 Cong Rec 3421 (1968).

${ }^{22}$ Gladstone, Realtors $v$ Village of Bellwood, 441 US 91, 111 (1979) (quoting Linmark, 431 US at 94). See also Metropolitan Housing Development Corp. $v$ Village of Arlington Heights, 558 F2d 1283, 1289 (7th Cir 1977)(" 'Congress has made a strong national commitment to promoting integrated housing .. ." (quoting Linmark, 431 US at 94)).

${ }^{23} 42$ USC $\S \S 2000 \mathrm{~d}$ et seq (1982). See University of California Regents v Bakke, 438 US 265 (1978).

42 USC 2000e et seq (1982). See Johnson, 107 S Ct 1442 (1987); Local 28 of Sheet Metal Workers u EEOC, 478 US 421 (1986); Weber, 443 US 193 (1979).

${ }^{95}$ See Bakke, 438 US 265 (1978) (rejecting the colorblind position that any racial classification is per se unconstitutional under the Equal Protection Clause). Of those justices currently on the Court, only Justice Rehnquist has expressly endorsed a colorblind view of the Equal Protection Clause. 
VI ${ }^{96}$ or not, like Title VII. ${ }^{97}$ Nevertheless, even under Title VII, the Court has steadfastly refused to give a colorblind reading to the statute's colorblind language and has upheld the constitutionality of race-conscious measures on a number of occasions. ${ }^{98}$ The remainder of this comment will therefore assume that the standards of the Fourteenth Amendment apply conterminously with those of Title VIII.99

\section{B. MACEs and the Proper Level of Judicial Scrutiny}

Modern equal protection doctrine subjects classifications that disadvantage certain racial classes, such as blacks, to a nearly per se rule of invalidity. While a classification scheme theoretically will pass so-called "strict scrutiny" whenever it is "narrowly tailored" to serve a "compelling" state interest, the Supreme Court's modern decisions have upheld such suspect classifications in only two instances, and those were during a time of national emergency. ${ }^{100}$ In light of such results, traditional strict scrutiny has aptly been described as " 'strict' in theory and fatal in fact."

The rationale for invoking strict scrutiny in suspect classification cases can be explained partially in terms of history. As the Supreme Court has stated, "[T] $]$ he clear and central purpose" of

${ }^{86}$ Id at 287 (1978) (Powell concurring in the judgment); id at 328 (Brennan, White, Marshall and Blackmun concurring in the judgment in part and dissenting in part).

${ }^{97}$ Johnson, $107 \mathrm{~S} \mathrm{Ct}$ at $1449 \mathrm{n} 6$ (1987); see also Weber, 443 US at $206 \mathrm{n} 6$.

8s See, for example, Johnson, 107 S Ct 1442 (1987); Local 28, 478 US 421 (1986); Weber, 443 US 193 (1979).

89 There are two well-established differences in the standards of analysis for Title VIII and the Equal Protection Clause, though neither are relevant to MACEs. First, unlike Title VIII, the Fourteenth Amendment applies exclusively to governmental activity. See Shelley $v$ Kraemer, 334 US 1, 13 (1948). Second, discriminatory intent must be present for a violation of the Fourteenth Amendment, while generally only discriminatory effects are necessary to establish a prima facie case for a violation of Title VIII. See Resident Advisory Board $v$ Rizzo, 564 F2d 126, 148 (3d Cir 1977). The State-sponsored implementation of any MACE necessarily entails, however benign the motive, an intent "to accord disparate treatment on the basis of racial considerations." Washington v Seattle School District No. 1, 458 US 457, 485 (1982).

${ }^{100}$ Korematsu $v$ United States, 323 US 214 (1944) (exclusion of Japanese-Americans from certain areas upheld on grounds of military danger from sabotage); Hirabayashi $v$ United States, 320 US 81 (1943). These cases now carry little precedential value. See Korematsu v United States, 584 F Supp 1406, 1420 (N D Cal 1984) (citing Fullilove v Klutznick, 448 US 448, 507 (1980) (Powell concurring)).

${ }_{101}$ Gerald Gunther, The Supreme Court, 1971 Term-Foreward: In Search of Evolving Doctine on a Changing Court: A Model for a Newer Equal Protection, 86 Harv L Rev 1, 8 (1972), quoted in Bakke, 438 US at 362 (opinion of Brennan, White, Marshall and Blackmun). See, for example, Loving $v$ Virginia, 388 US I (1966) (miscegenation laws violated equal protection and due process); Yick Wo $v$ Hopkins, 118 US 356 (1886) (racially-neutral law held violative of equal protection because of disproportionate impact on Chinese). 
the Equal Protection Clause is "to eliminate all official state sources of invidious racial discrimination in the States."102 A more functional explanation, however, is that strict scrutiny and the accompanying strong presumption of invalidity reflect a belief that the Equal Protection Clause prohibits, above all, measures enacted by majorities who may be motivated by prejudice toward disadvantaged groups. ${ }^{103}$

Despite the traditional strict scrutiny framework for examining racial classifications, the Supreme Court has, in practice, subjected affirmative action programs to less than strict scrutiny. Though some members of the Court have described their analysis of affirmative action programs as "strict scrutiny,"104 these justices have, in fact, applied a "sub-strict" level of scrutiny; that is, a slightly higher level than the so-called "intermediate" level of scrutiny endorsed by other members of the Court, ${ }^{105}$ but a lower level than traditionally fatal strict scrutiny. Not surprisingly, the confusing nature of these various levels of scrutiny has prompted at least one member of the Court to advocate formal abandonment of the "tiered" constitutional analysis altogether in favor of a simple balancing test. ${ }^{108}$

The Court has departed from traditional strict scrutiny in affirmative action cases essentially because there is less reason to question legislation when it is not motivated by prejudice, and is designed to help blacks by remedying prior discrimination. In such cases, the evil at which the Equal Protection Clause is aimed is less likely to be present. The Brennan block in Bakke noted that

\footnotetext{
${ }^{102}$ Loving, 388 US at 10. See also Bakke, 438 US at 291 (Powell) (noting that the Court's initial view of the purpose was more limited).

${ }^{103}$ United States v Carolene Products, 304 US 144, 153 n 4 (1938). See also John Hart Ely, Democracy and Distrust 75-77 (Harvard, 1980) and those who argue, on normative grounds, that the equal protection doctrine should be used to prevent or eliminate the social subordination of various disadvantaged groups. See Owen M. Fiss, Groups and the Equal Protection Clause, 5 Phil \& Pub Aff 107 (1976); Catharine A. MacKinnon, Feminism Unmodified (Harvard, 1987); David A. Strauss, The Myth of Colorblindness, 1986 Sup Ct Rev 99.

${ }^{104}$ See Wygant, 476 US at 247 (1986) (plurality opinion of Powell, Rehnquist, Burger, and O'Connor) (the means chosen must be "narrowly tailored" to achieve a "compelling state purpose"). See also Bakke, 438 US at 291 (Powell).

${ }^{105}$ For endorsements of intermediate scrutiny, see Wygant, 476 US at 301-302 (Marshall, dissenting, joined by Brennan and Blackmun) (remedial use of race is permissible if it serves "important governmental objectives" and is "substantially related to achievement of those objectives"); Fullilove v Klutznick, 448 US 448, 519 (1980) (Marshall, concurring in judgment, joined by Brennan and Blackmun).

${ }^{106}$ See Wygant, 476 US at 320 (Stevens dissenting) (in Title VII action, public interest must be served by racial classification and means employed must justify adverse effects on the disadvantaged group).
} 
whites, unlike blacks, were "not saddled with such disabilities, or subjected to such a history of purposeful unequal treatment, or relegated to such a position of political powerlessness as to command extraordinary protection from the majoritarian political process." 107

Of course, a key issue for purposes of this comment is determining where the MACE fits into this general framework. On the one hand, MACEs are not like traditional racial classifications, since their purpose is fundamentally remedial. MACEs, like affirmative action programs, are intended to help rather than harm blacks as a class; they are aimed at eliminating social subordination, rather than perpetuating it. Under this reasoning, MACEs should not be subjected to the per se rule of invalidity of traditional strict scrutiny.

On the other hand, because individual blacks are the shortterm victims of the measures, MACEs are distinguishable from affirmative action programs. There is a danger that MACEs will be used as devices of invidious discrimination in order to keep an unreasonably large number of blacks out of a community relative to the community's actual tipping point. Even if the legislature is not motivated by racial animus per se, there might nonetheless be a tendency for majorities, who are not themselves burdened by MACEs, to overestimate the risk of tipping and thereby inflict unnecessary harm on individual blacks. ${ }^{108}$ Primarily for these reasons, even those judges who have advocated an intermediate level of scrutiny for access quotas have distinguished those types of quotas from ceiling quotas. ${ }^{109}$

Courts should thus examine MACEs under a form of scrutiny that is more searching than that used for affirmative action programs. Because racial classifications that disadvantage minorities are involved, courts should examine MACEs under strict scrutiny, but not in as hypocritically conclusive a manner as the Court has previously used. Strict scrutiny, as its name suggests, should describe a scrutiny that is strict in theory, but not fatal in fact.

With this in mind, the remainder of this comment will examine the legality of MACEs in terms of strict scrutiny, but will

${ }^{107} 438$ US at 357 (Brennan, White, Marshall and Blackmun, concurring in part and dissenting in part).

${ }^{108}$ See Ely, Democracy and Distrust at 156-62 (cited in note 103).

${ }^{108}$ See Bakke, 438 US at 375 (Brennan, White, Marshall and Blackmun dissenting), quoted in Fullilove, 448 US at 521 (Marshall, Brennan and Blackmun concurring in judgment). 
not undertake the illusory task of quantifying the differences in degree between any given MACE and other racial classifications. In brief, this comment will argue that, because MACEs in principle serve compelling societal ends, any given MACE program should be upheld, provided that it is sufficiently narrowly tailored toward the fulfillment of those ends.

C. The First Prong of Strict Scrutiny: Serving "Compelling" Ends

\section{The difficulty of defining "end."}

Perhaps MACEs are best understood as a catalyst for a number of effects that, although ends in and of themselves, also constitute means to other, more compelling ends. Thus, MACEs are means to the end of artificially-maintained residential integration. This, in turn, is a means to the end of altered societal attitudes about interracial living patterns. These altered societal attitudes, in turn, are a means to the end of reducing, and eventually eliminating, the potential for tipping. Such a result can ultimately lead to naturally-arising, integrated living patterns, reduced racial tension, and the societal benefits and opportunities that accompany integration.

Therefore, it becomes difficult, if not impossible, to define the end of MACEs for purposes of examining whether or not it is compelling. While a number of those ends mentioned could be considered sufficiently compelling, when they are observed together, the ends sought by MACEs should be deemed more than sufficient to survive strict scrutiny analysis.

\section{MACEs as means to remedial ends in areas other than housing.}

In the context of affirmative action, the Supreme Court has held that eradicating the actual effect of illegal race discrimination is a sufficiently "compelling" interest for strict scrutiny purposes. ${ }^{110}$ MACEs may not produce a remedial end in the narrow

110 See, for example, United States v Paradise, 480 US 149 (1987) (holding 50 percent promotion requirement permissible under Equal Protection Clause in that it was justified by compelling governmental interest in eradicating discriminatory exclusion of blacks from Alabama Department of Public Safety positions); Johnson, $107 \mathrm{~S} \mathrm{Ct} 1442$ (upholding affirmative action plan directing that sex in hiring be considered for purpose of remedying underrepresentation of women in traditionally segregated job categories); Fullilove, 448 US 448 (1980) (access quota for governmental business contracts to selected minorities upheld under Equal Protection Clause); Weber, 443 US 193 (1979) (Title VII held not to forbid all 
sense of remedying the effects of an isolated actor's civil rights violations, but they nevertheless constitute means to achieve many compelling remedial goals - most notably, in the educational and employment contexts. As Gary Orfield has written:

Housing segregation and the possibility of integrated housing are so important to our future because race is the central structural problem of American urban society and because a family's spatial location determines so much in our sprawling, highly segregated metropolitan areas. It not only determines whether or not one's children will grow up in a multiracial setting with friends of different groups but it also determines the quality of schools, the level of municipal services, increases in housing value, relative tax burdens, ease of access to work, safety, and much else. ${ }^{111}$

One could argue, for example, that residential integration can result in school integration without the disruptions and costs of busing. ${ }^{112}$ In addition, suburban integration may catalyze private investment over a greater geographical area, thereby allowing blacks to gain greater access to job opportunities that have accompanied the white exodus from deteriorating cities. ${ }^{113}$ Thus, the creation of various educational and employment opportunities may well constitute a sufficiently compelling interest to justify, in principle, the use of MACEs.

\section{MACEs and correction: Ending societal discrimination.}

While the Supreme Court has not expressly stated as much, its holdings suggest that a finding of past discrimination is necessary to uphold an affirmative action plan under the Equal Protection Clause, but not under Title VII. For example, in Bakke and Wygant, the Court invalidated affirmative action plans on equal protection grounds, stating in the latter that "[s]ocietal discrimination, without more, is too amorphous a basis for imposing a racially classified remedy." 114 Conversely, in United Steelworkers $v$ Weber and Johnson $v$ Transportation Agency of Santa Clara County, the Court upheld affirmative action plans under Title VII, even though

private, voluntary, race-conscious affirmative action plans).

11 Orfield, The Movement for Housing Integration at 18 (cited in note 30).

112 Note, 93 Harv L Rev at 954 (cited in note 2).

113 Id. See also Orfield, The Movement for Housing Integration at 18, 20 (cited in note $30)$.

114 Wygant, 476 US at 276 (plurality opinion of Powell, Burger, Rehnquist and O'Connor). 
there had been no evidence of prior discrimination by the employer in either case. Specifically, in Johnson, the Court held that an employer "need not point to its own prior discriminatory practices" but instead could justify its plan by the existence of a "conspicuous ... imbalance in traditionally segregated job categories.' "115

Just as the employer plans in Weber and Johnson acted as a corrective device to eradicate the effects to the work force caused by societal discrimination, so too are MACEs a corrective and remedial device for the effects to housing patterns caused by racial discrimination generally. In this sense, decreased discrimination that is generated indirectly by MACEs might well be considered a compelling end, at least under Title VIII.

Furthermore, although the Supreme Court, under the Equal Protection Clause, has not yet sanctioned an affirmative action program that was not remedial, at least five justices have indicated that there may be other sufficiently "compelling" bases for such a program. Justices Brennan, Blackmun, and Marshall have stated their belief that the scope of an affirmative action policy "need not be limited to remedying specific instances of identifiable discrimination."116 In addition, Justice O'Connor has remarked that there may be "other governmental interests ... [ [that are] sufficiently 'important' or 'compelling' to sustain the use of affirmative action policies."117 Finally, Justice Stevens has opined that, rather than require a showing of past discrimination, the Court should employ a simple balancing test, weighing the public interest advanced by a program against any adverse effects that program might have on disadvantaged groups. ${ }^{118}$ These remarks indicate that, under proper circumstances, a majority of the present Court would permit forward-looking programs, such as MACEs, under the Equal Protection Clause as well as Title VIII.

In the sense that MACEs represent a corrective policy by the State, they are similar to the school desegregation cases. In rejecting the "separate but equal" doctrine, the Supreme Court recognized that some measure of forced integration would be necessary in order to provide black school children with equal

118 Johnson, $107 \mathrm{~S} \mathrm{Ct}$ at 1451 (quoting Weber, $443 \mathrm{US}$ at 212 (Blackmun concurring)). See also id at 1469 (Scalia dissenting, joined by Rehnquist and White) (the majority "permits discrimination under Title VII when it is intended to overcome the effect, not of the employer's own discrimination, but of societal attitudes ....").

${ }^{116}$ Wygant, 476 US at 305 (Marshall dissenting, joined by Brennan and Blackmun).

${ }^{117}$ Id at 286 ( $O$ 'Connor, concurring in part and concurring in the judgment).

11 Wygant, 476 US at 313 (Stevens dissenting). 
educational opportunities and to "undo" the warped attitudes that had been produced by de jure segregation. ${ }^{119}$

This approach to correcting societal attitudes was particularly evident in the busing cases. In Swann $v$ Charlotte-Mecklenburg Board of Education, ${ }^{120}$ for example, the Court upheld a district court's order that the school board integrate schools to reflect the racial makeup of the school system, in which 71 percent of the students were white and 29 percent were black. Writing for the Court, Chief Justice Burger noted "that in order to prepare students to live in a pluralistic society each school should have a prescribed ratio of Negro to white students reflecting the proportion for the district as a whole."121 The Chief Justice also declared that "[w]hen school authorities present a . . . 'loaded game board,' affirmative action in the form of remedial altering of attendance zones is proper to achieve truly nondiscriminatory assignments." 122 Thus, the outcome-oriented measure of busing was permitted in order to foster equality of opportunity, both before and after graduation from school, by means of changing the perceptions and attitudes of school students.

It should be noted that the Supreme Court, at least in its rhetoric, still maintains a de jure/de facto distinction in busing and seeks to remedy the effects of only intentional (de jure) governmental discrimination. ${ }^{123}$ One could easily reconcile this seeming inconsistency between MACEs and busing remedies by questioning the sincerity of the Court's rhetorical distinction. However, even taking the de jure/de facto distinction at face value, the differing role that societal expectations play in the housing and busing areas indicate that such a distinction is inapplicable to MACEs. That is, in the busing context, corrective attitudinal effects are only a byproduct of rectifying intentional governmental discrimination. In the housing context, though, the corrective effects generated over time by MACEs serve as a necessary means to achieve the end of a long-term integrated society and the salutary effects that it, in turn, fosters. As such, correction of attitudes in the MACE context is an integral and essential link in the chain leading to truly integrated housing patterns, not merely a by-product. Thus, a de jure/

119 See, for example, Brown v Board of Education, 347 US 483 (1954); Brown v Board of Education, 349 US 294 (1955); Green v County School Board, 391 US 430 (1968).

${ }^{120} 402$ US 1 (1971).

121 Id at 16.

122 Id at 28.

${ }^{123}$ See Pasadena City Bd. of Educ. v Spangler, 427 US 424 (1976); Keyes $v$ School Dist. No. 1,413 US 189 (1973). See also Brown v Board of Education, 347 US 483 (1954). 
de facto distinction serves no purpose in the housing context where, unless attitudes are changed artificially, integrated living patterns will never occur naturally.

\section{MACEs and pragmatism: Promoting societal integration.}

Justification for the implementation of MACEs can be conceptualized either as the benefits to be gained from an integrated society, or as the harms to be avoided from a segregated society. The present section is concerned with these alternative conceptualizations.

In Trafficante $v$ Metropolitan Life Insurance Co., ${ }^{124}$ Gladstone, Realtors $v$ Village of Bellwood, ${ }^{125}$ and Havens Realty Corp. $v$ Coleman, ${ }^{126}$ the Supreme Court, taking an extremely liberal view of standing under the Fair Housing Act, repeatedly emphasized the benefits that flow from interracial associations, and the social, professional, and economic and other losses that resulted from unlawful steering practices. The language used by the Court in these opinions lends strong support to the argument that MACEs, at least in principle, should be deemed constitutional.

In Trafficante, Justice Douglas, writing for the Court, held that the loss of important benefits from interracial associations was a sufficiently palpable injury to confer standing to sue under the Fair Housing Act. ${ }^{127}$ Similarly, in Gladstone Realtors the Court concluded that " ' $t]$ here can be no question about the importance' to a community of 'promoting stable, racially integrated housing." "128 Justice Powell, in noting the "profound" nature of "[t]he adverse consequences attendant upon a "changing' neighborhood," specifically referred to the tipping phenomenon:

If petitioners' steering practices significantly reduce the total number of buyers in the Bellwood housing market, prices may be deflected downward. This phenomenon would be exacerbated if perceptible increases in the minority population directly attributable to racial steering precipitate an exodus of white residents .... A significant reduction in property values directly injures a municipality by diminishing its tax base, thus threatening the ability to bear the costs of local govern-

124409 US 205 (1972).

${ }^{125} 441$ US 91 (1970).

128455 US 363 (1982).

${ }^{127} 409$ US at 210.

${ }^{128} 441$ US at 111 (quoting Linmark Associates, Inc. $v$ Willingboro, 431 US 85, 94 (1977)). 
ment and to provide services. Other harms flowing from the realities of a racially segregated community are not unlikely. ${ }^{128}$

Finally, in Havens Realty Corp., the Supreme Court reaffirmed that standing existed to contest the social, professional, and economic losses that resulted from racial steering practices. ${ }^{130}$

The Supreme Court's remarks do not establish that it would uphold the constitutionality of all MACEs. Each of these cases involved an alleged instance of discrimination by an identified private party, and each case actually held only that standing existed under Title VIII to sue for the loss of associational benefits resulting from resegregation. MACEs, on the other hand, would often be employed even when there was no instance of identified discrimination. Thus, while the standing cases discussed above are concerned with eliminating ongoing malicious discrimination against blacks in the housing market, MACEs pose an unresolved dilemma: whether discrimination against individual blacks is permissible in order to promote forward-looking goals that are beneficial to blacks and society as a whole.

Although the standing cases should not be interpreted as an outright endorsement of MACEs, they nonetheless emphasize the benefits that flow from interracial associations, as well as the harms that may be inflicted by tipping and white flight. In this manner, they may be viewed at least as endorsing the proposition that promoting and maintaining integrated living patterns is a compelling end in and of itself. The Gladstone Realtors opinion, in particular, noted the legitimacy of a community taking steps to prevent the occurrence of tipping. Exactly how far a community may "step" in its implementation of MACEs is determined by the second prong of strict scrutiny analysis, which examines whether a given MACE is "narrowly tailored" toward the achievement of its compelling ends.

To summarize, MACEs generate immediate as well as enduring benefits, including the achievement of many remedial goals in the employment and educational fields, the reduction of racial tension generally, and the promotion of naturally arising, integrated living patterns. At the same time, MACEs allow a community to avoid the numerous harms that flow from the realities of a racially segregated community. In brief, while any of these ends may be 
considered compelling by themselves, when combined, these ends are certainly sufficient to satisfy the first prong of strict scrutiny analysis.

D. The Second Prong of Strict Scrutiny: Narrowly Tailoring MACEs to their Ends

\section{The general balancing approach.}

Once one agrees in principle that MACEs are a means to reach a compelling end, the remaining question is whether any given MACE is "narrowly tailored" toward the achievement of that end. ${ }^{131}$ Due to the wide variety of factors that figure into the calculus of determining a given community's tipping point, it is impossible to formulate any bright line rule for evaluating the validity of MACEs. Suffice it to say that, in every given instance, a balancing test will have to be administered whereby the benefits to be gained from any given MACE are weighed against the societal costs that MACE will necessarily impose.

Of course, the relative weight assigned to factors will be extremely difficult to gauge. A strict utilitarian approach, for instance, would not be in order. At the same time, great weight should necessarily be given to the potential benefits of an integrated community, so at least some burden on black third parties would appear to be justified.

Although the Court has not laid down a formula for determining what is "narrowly tailored," it has cited a number of factors that should be considered, including: (1) whether a program is reasonably necessary, (2) whether a program stigmatizes any social group, (3) whether a program unnecessarily trammels the rights of innocent third parties, and (4) whether a program is modest and temporary in nature. ${ }^{132}$ The following sections will examine MACEs under each of these factors, but will also indicate why such guidelines are often not wholly applicable to the housing context.

2. Whether a MACE is reasonably necessary.

This factor is unfortunately illusory because the term "neces-

131 See Wygant, 476 US at 274 (plurality opinion).

132 See Paradise, 480 US at 171; id at 187 (Powell concurring); Local 28, 478 US at 481 (Brennan concurring); id at 485 (Powell, concurring in part and concurring in judgment); Wygant, 476 US at 279-282 (opinion of Powell); id at 284 (O'Connor, concurring in part and concurring in judgment); id at 312 (Marshall, dissenting, joined by Brennan and Blackmun). 
sary" can be conceptualized in at least three different ways, possibly leading to different results: whether MACEs in the general sense are necessary, whether it is necessary for a particular community to adopt a MACE program, or whether any particular MACE is reasonably necessary in a given instance.

a) The general necessity of MACEs. Possibly the strongest argument against MACEs generally is that they are not the least intrusive means to achieve the end of integration. This argument usually rests on the assumption that the market will ultimately illustrate the benefits of integrated living patterns and change societal attitudes as effectively as could MACEs. The net result will be integrated living patterns without the intrusive effect of governmental interference and paternalism. Yet, even if one accepts the theory that the market provides the optimal long-term solution, the short-term costs of segregation may be too great to bear.

Another argument against the general "necessity" of MACEs is that there is no qualitative difference between segregated living patterns and integrated living patterns. Such an argument follows along the lines of the "separate but equal" doctrine, and may be refuted in the manner that the Court refuted it in Brown $v$ Board of Education; namely, that separate living patterns are inherently. unequal living patterns. ${ }^{133}$ In every area of society, the prejudice nurtured by segregated living patterns will have marked effects, and will effectively preclude equal educational, cultural, and employment opportunities for blacks. In addition, to the extent that such an argument rests on notions of governmental neutrality, it is fallacious. Hardly a question of "whose ox is being gored,"134 as Herbert Wechsler contended, State preservation of the status quo in fact maintains an inequitable, non-neutral baseline from which remedial action may be constitutionally mandated. ${ }^{135}$

b) The particular community's need to adopt a MACE program. While this comment argues that the general necessity of MACEs should be upheld in principle, it would be absurd to argue that, because of this, communities should be given a majoritarian carte blanche to enact any MACE policy that they choose. A community must be responsible for demonstrating that it has a firm basis for concluding that a MACE program is necessary to combat a perceived threat of tipping. Of course, whether such a policy is in fact necessary can only be ascertained on a case by case basis.

\footnotetext{
${ }^{133}$ See Brown v Board of Education, 347 US 483, $493-95$ (1954).

${ }_{134}$ Wechsler, 73 Harv L Rev at 1 (cited in note 55).

${ }^{135}$ See Sunstein, 87 Colum L Rev at 894-98 (cited in note 55).
} 
It bears emphasis that a court's examination in this regard is wholly distinct from its examination of the necessity of a particular type of MACE, which is the subject of the following subsection. In effect, a court must first examine whether a community had a firm basis for concluding that a problem even exists; only then can a court evaluate whether the community's proposed solution to that problem is the best available.

Several factors will be relevant in determining what constitutes a "firm" basis for implementing a MACE: the existence of findings; the making of findings by a competent decisionmaker; the nature of the decisionmaker and fact gatherer (for purposes of examining likelihood of prejudice); the explicitness of the MACE; the likelihood of invidious motivation. In essence, the standard will vary from case to case, depending on the relative costs and benefits generated by the particular MACE program, and should thus be examined in cost-benefit terms. ${ }^{136}$

c) The necessity of a particular type of MACE. The necessity of any individual MACE will be entirely a function of the costs and benefits it generates relative both to other possible MACEs and to alternative courses of action.

Often objections to individual MACEs are erroneously phrased as objections to MACEs in general. For example, critics cite to "racially neutral" alternatives to MACEs, such as increased monitoring of realtor steering practices, improved public facilities, and screening for problem families. Yet this argument does not constitute criticism of MACEs generally, but merely advocacy of less intrusive, implicitly race-conscious MACEs. This criticism, then, is reflective only of a more flexible approach to the balancing test; that is, the benefits to be gained from some implicitly race-conscious MACEs will outweigh the respective costs such MACEs impose. However, these critics would apparently draw the balancing line at any explicitly race-conscious MACE.

Such an argument is deficient in a number of respects. Most notably, it fails to recognize that particular circumstances will alter the relative benefits and burdens created by any given MACE. In addition, it draws an illogical and arbitrary line. On the one hand, advocates of this view would invalidate MACEs if individual black and white homebuyers were steered during their search for housing. On the other hand, these same people would uphold MACEs that had an identical purpose, but that could create less effective 
results at greater costs of implementation than more direct MACEs.

In response, proponents of this view might contend that the stigmatic costs to individuals are prohibitive in the case of explicitly race-conscious MACEs. Yet this is an overgeneralization. As a general matter, to say that a quota will be "stigmatizing" is a conclusory statement, devoid of any inquiry into important issues such as the causes and motivations that combine to produce stigma. With the possible exception of quotas, explicitly race-conscious MACEs are no more stigmatizing to blacks individually than are implicitly race-conscious MACEs. It may be that the system of MACEs itself is stigmatizing to blacks as a group, but the system is no more stigmatizing as it applies to implicitly race-conscious MACEs than as it applies to explicitly race-conscious MACEs. In sum, drawing an arbitrary line at explicitly race-conscious MACEs is an untenable position.

Apparently sensing this conclusion, a number of commentators have advocated explicitly race-conscious MACEs, but for reasons apparently grounded in stigmatic costs, would draw the line just short of implementing MACE quotas. This is a much more sustainable position and will be examined in the next section.

\section{Whether a program stigmatizes any group.}

a) Less direct MACEs. The tipping phenomenon that motivates MACEs suggests that many whites see black communities as "ghettos," and assume that any large influx of blacks will inevitably result in the deterioration of the neighborhood. The black homebuyer faced with a MACE quota, and aware that this negative image is preventing the purchase of a home, may very well feel stigmatized. Only MACE quotas, however, involve such an overt bar to entry into a neighborhood. Indirect MACEs, involving greater freedom of choice, presumably produce less direct, and more attenuated, stigmatic effects. Nonetheless, it may be argued that any MACE device is stigmatizing in that it constitutes an official "approval" of the racist attitudes that lie at the heart of white flight.

Such an assertion is based on a number of incorrect assumptions. First, to the extent that white flight is determined by racist sentiments, MACEs do not represent State "approval" of those attitudes, any more than court-ordered busing represents "approval" of segregated schools. MACEs represent merely a recognition that prejudice exists in the world. Precisely because of that recognition, MACEs effectively correct this prejudice by promoting integrated 
living patterns. One important point should not be overlooked in this regard: at a very basic level, MACEs constitute no more than a State effort to deal with resistance to minority entry by flight, rather than resistance by obstruction. ${ }^{137}$

Second, while prejudice as a motivating factor for white flight cannot be disregarded, it is a distorting oversimplification to explain the "resegregation syndrome," and the conduct of white homeowners who fear it, solely in terms of white prejudice. ${ }^{138}$ Fears of hostility and isolation, of declining property values and a dwindling tax base, often make the choice to leave a rational human decision in unhappy circumstances. ${ }^{139}$ Residents may decide to leave a community not so much because of their own prejudice, but rather because they fear that others will flee the community due to racist motivations. Similarly, residents fear that resegregation will prompt property values to decline not because the residents equate a predominantly black community to that of a "ghetto," but because they reasonably fear that prospective homebuyers will view it as such. Just as the implementation of MACEs represents a governmental recognition that prejudice exists, such recognition on an individual level leads to white flight.

b) MACE quotas. In those instances where a quota is the only viable means for a community to prevent tipping, the critics fail to grasp the stigmatizing effects that would result from not implementing MACE quotas. As Professor Gewirtz has noted:

Although grappling with imperfection may be difficult, it is part of the difficulty of the remedial problem, of translating ideals into something real that makes the world somewhat better for at least some people. To reject the imperfect may preserve the horrible. ${ }^{140}$

The "horrible" to be preserved in the absence of MACE quotas is quite simply an endless perpetuation of tipping and resegregation.

Nonetheless, taking stigma into account, the costs associated with MACE quotas exceed those costs entailed by less direct forms of MACEs, all else being equal. However, all else is never equal. For example, it may well be more financially efficient for a community to maintain racial balance via quotas than by an elaborate network of devices that manipulate choice; financial costs might

${ }^{197}$ See Gewirtz, 92 Yale L J at 629 (cited in note 46).

${ }^{13}$ See Polikoff, Issues in Housing Discrimination at 205 (cited in note 52).

139 Id.

140 Gewirtz, 92 Yale L J at 660 (cited in note 46). 
thus overshadow stigmatic costs. In addition, the stigmatic costs entailed by quotas, if handled tactfully and openly, need not be as significant as one might initially think. Therefore, there may be a number of instances where the total costs of maintaining racial balance by means of MACE quotas are less than the total costs of other less direct and stigmatic MACEs. In such cases, the quota should be preferred relative to those other MACEs, and should be upheld.

4. Whether MACEs unnecessarily trammel the interests of individual blacks.

Closely related to the subject of stigmatization is whether a program unnecessarily trammels the interests of black homebuyers. The Supreme Court has expressed concern about this consequence of an affirmative action plan on a number of occasions. ${ }^{141}$ Note how the tension posed by MACEs differs from traditional affirmative action plans in this respect: in affirmative action, the conflict is whether members of a majority race should be made to suffer some disadvantages in order to give other advantages to members of a minority race. With MACEs, however, the problem is whether minorities should "bear the social cross of the benign goal of integration."142 This problem can only be resolved on an ad hoc basis, as determined by the particular circumstances presented by any given MACE.

A potentially much more troubling aspect of MACEs is that they might be over- or under-inclusive in the consequences they produce for other ethnic groups aside from whites and blacks. One could argue that if MACEs are extended to their logical end, then Native Americans, Asians, Hispanics, Italians, and other ethnic groups should also figure into the racial balancing calculus entailed by MACEs. In fact, to do otherwise, would seem to deny those groups the benefits to be gained from living in an integrated society, and thereby the equal protection of the laws.

In areas where one or more of these ethnic groups is concentrated in large numbers, MACEs of this type may be desirable. For example, in southern California, the Hispanic population is so large that MACEs would be much more effective for that group

141 See Local 28, 478 US at 479; Weber, 443 US at 208. Of course, these cases dealt with trammelling the interests of whites, not blacks.

${ }^{142}$ See 2 Issues in Housing Discrimination: A Consultation/Hearing of the United States Commission on Civil Rights 50, 51 (Nov 12-13, 1985) (remarks of Rodney A. Smolla). 
relative to the white population, than for blacks in that area. ${ }^{143}$ However, it must be remembered that the purpose of MACEs is not to create a community that "mirrors" the racial make-up of society generally. Instead, the purpose of MACEs is to combat the very specific problem of tipping and white flight. Thus, unless one or more of these groups presents a realistic threat of tipping to a community, there is no need to figure those groups into the MACE calculus.

\section{Whether MACEs are modest and temporary.}

In upholding affirmative action plans, members of the Supreme Court have sometimes noted that the particular plan in question was temporary in nature. ${ }^{144}$ Critics argue that MACEs do not share this trait; that is, rather than seeking to attain a racial balance, MACEs seek to maintain a desired racial balance indefinitely.

The "temporary" standard is a useful guideline in determining whether a race-conscious remedy is being continued after it has already fulfilled its function, and is thereby unnecessarily burdening a particular group. However, it is pointless to apply the same time horizon to MACEs as that used for affirmative action plans. Certainly MACEs should be in place only as 'long as they are needed to cure a perceived threat of tipping. Yet one cannot realistically expect societal attitudes to change in the time that has traditionally been allotted to affirmative action programs, which do not rely on changing societal attitudes for their success.

To ask if a MACE is "modest" is merely another way of asking whether a MACE is unnecessary, or whether it is stigmatizing, or whether it unnecessarily trammels the interests of individual blacks. In other words, "modesty" is an overlapping criterion that dissembles the pragmatic balancing test that must be administered vis-a-vis any given MACE. As such, the issue has already been discussed in other sections of this comment.

${ }^{143}$ For a case study of discrimination against Hispanics in the Denver, Phoenix and Houston areas, see Franklin J. James and Eileen A. Tyman, Segregation and Discrimination of Hispanic Americans, in Goering, ed, Housing Desegregation 83 (cited in note 2).

${ }^{144}$ See, for example, Paradise, 480 US at 183 (promotion requirement would be only temporary, and subject to amelioration); Johnson, $107 \mathrm{~S} \mathrm{Ct}$ at 1464 ( $\mathrm{O}^{\prime}$ Connor, concurring in the judgment)(long-term goal of hiring plan was to attain a work force which approximates the distribution of females in work force). 


\section{Judicial Standards for Evaluating MACEs}

Because this comment has argued that all MACEs fulfill a compelling governmental interest in principle, a court's evaluative task should necessarily be confined to determining, first, whether it was necessary for a particular community to adopt a general program of implementing MACEs, and, if so, whether the particular MACE in question is "narrowly tailored" toward the achievement of its intended goals.

A general program of implementing MACEs should be permitted in those instances where the evidence demonstrates a reasonable concern by community decision-makers that tipping would occur if current housing trends continued unchecked. Except where an imminent threat of tipping mandates drastic and immediate measures, a decision to implement a general program of MACEs will not be "reasonable" unless backed by prior studies of residential buying trends within the general area and documented estimations of the particular community's tipping point. However, because MACEs seek to remedy the effects to living patterns produced by societal discrimination generally, a community need not make findings of prior discrimination by an identified actor. In those cases where the community entertains a reasonable perception of imminent tipping, the community will be required to make a contemporaneous finding that the measures currently being employed are necessary. In all cases, the community will be required to perform periodic reevaluations of area buying trends in order to determine whether or not continued use of the particular MACE is necessary.

Even if a community rationally concluded what its tipping point would be, a court must strike down a general MACE program if the target black population is set unreasonably lower than that tipping point. Note that, when examining a community's calculation of its estimated tipping point and its adoption of a black target population beneath that point, courts must be especially mindful of the potential for overexclusion of blacks from the community under the guise of preventing tipping. One caveat bears emphasis: because the judicial branch is no more competent than other branches to evaluate statistical sociological evidence of tipping, a court should be somewhat deferential to legislative determinations in this regard, and employ primarily a motivational analysis of legislative conduct. ${ }^{148}$ 
If a court determines that a community had a firm basis for concluding that a general program of using MACEs was necessary, then a court should permit the particular MACE in question unless either (1) there is clear and convincing evidence that a less direct MACE, or theoretically no MACE at all, would provide comparable societal benefits at less societal cost, or (2) the community's tipping point had been projected at so low a level that, due to the limited number of blacks in the community, integrated living patterns could not reasonably be said to exist after implementation of the MACE. If the second problem arises, the stigmatic costs of implementing that MACE program will necessarily outweigh the negligible, if existent, benefits accruing from the MACE program. As such, the MACE program should be struck down, even if the only alternative to the program is resegregation.

A final point should be emphasized. Since the partial intended effect of MACEs is to allay fears of white flight, a community's tipping point will necessarily be somewhat higher after a given MACE has been implemented. To reflect this, the projected tipping point should be calculated and evaluated at the level it would be after the MACE's implementation. Thus, in some instances, particularly in the quota context, MACEs could reasonably be used to reach a "target" black population in excess of the community's tipping point ex ante. The irony is that, the more direct the MACE, the greater will be the number of blacks who will be able to enter a community and still allow it to retain integrated living patterns. ${ }^{146}$

\section{CONCLUSION}

This comment has argued that all forms of MACEs, including quotas, should be legal under the Equal Protection Clause of the Fourteenth Amendment and the Fair Housing Act, provided that the costs entailed by any given MACE do not exceed the benefits resulting from that MACE. Rather than undertake the illusory task of quantifying costs and benefits, I have sought only to es-

tional analysis has become a favored and well established approach of the Court, particularly in the equal protection sphere. See, for example, Davis $v$ Bandemer, 478 US 109 (1986); Personnel Administrator v Feeney, 442 US 256 (1979); Arlington Heights v Metropolitan Housing Dev. Corp., 429 US 252 (1977); Washington v Davis, 426 US 229 (1976).

${ }^{148}$ Oscar Newman, the defendant's expert witness in the Starrett City case, has predicted that the use of MACE quotas could double the number of minorities in communities without prompting resegregation. Remarks at Potomac Institute/NCDH Legal Fair Housing Conference, Washington, D.C. (Jan 10, 1985) (cited in Goering, Introduction, Housing Desegregation at 1,14 (cited in note 2$)$ ). 
pouse a general analytic framework. Within that framework, I have argued that the general costs of MACEs are lower, and their corresponding benefits higher, than might first be imagined.

Colorblind antidiscrimination policies have failed to produce long-term stability in the housing market. Courts must recognize that the only way stable, integrated living patterns will naturally arise in the long-term is to create and maintain those patterns artificially in the short-term. Community tipping points need to be raised, and the best way to accomplish that is to demonstrate to society the benefits that will flow from interracial associations. The solution is admittedly imperfect, for some political, cultural and stigmatic costs to individual blacks are unavoidable. Nevertheless, MACEs present the only viable alternative to the far more imperfect alternative of perpetual segregation and resegregation. 